forming logical operations on problems in the social sciences is subject to limitations, if less extreme, through lack of precise meaning. Mr. Brinton, reviewing the various meanings which progress has borne, refers first to the sense of improvement in a process or technique. Then there is the sense derived from theories of organic evolution developed in the last century or so, and finally the sense of moral or social progress. He points out that so long as the notion of progress is closely associated with our immediate notions of the difference between what is and what ought to be, progress will probably remain one of the most important ethical abstractions in common use. In a third paper, Prof. E. B. Wilson suggests that no scientific meaning can be attached to such a term as social progress until social science has advanced considerably further as a science, and social studies are unlikely to become scientific so long as the mores of our social scientists place brilliancy so far ahead of patience and generalities so far ahead of specification. We need a handbook of the social sciences which tells us what is true under what restrictive conditions. Until such coherent growth has begun and gained considerable momentum we shall probably not have the background on which to say what is social progress, and when social science has thus advanced we shall be talking rather in terms of various sorts of social progress and social retrogression.

\section{The City and South London Railway}

ON November 11 the City and South London Railway celebrated its jubilee. The one outstanding criticism of this railway which could have been made was that the designers of the new line built for conditions then existing, and failed to take into account the changes that would occur in a few years' time. For example, the tunnel diameter was much too small, so were the first locomotives, the trains and the cars. The diameter had to be increased in 1922, and extensions were made for the railway between Stockwell and King William Street. It would appear that the railway made too timid a beginning. The Electrical Times, which also began its career about fifty years ago as Lightning, has referred to its earlier criticisms of the railway, and points out that perhaps its promoters dared not venture too far on what, after all, was an experiment without precedent ; for the City and South London was the first electric tube railway ever built.

The new rolling stock has been designed to obtain the maximum amount of seating capacity consistent with comfort, and also allows a very much greater standing space than the old rolling stock. It has not been possible to introduce the new stock gradually, as part of the improvement of this railway is the moving of the conductor rail from its original position centrally between the running rails to the standard position laid down by the Ministry of Transport, namely, 16 in. outside the running rail ; $6,445 \mathrm{yd}$. of new conductor rail have been laid. In order to reduce noise to a minimum, the running rails have been welded into 315 - ft. lengths, involving 544 welded joints. Noise-absorbing shields are also being experimented with. These shields are fitted between the lower portion of the coaches and the tunnel walls. The City and South London is London's shortest tube railway. It is only 1 mile 46 chains long, and forms part of the quickest route from the heavily populated south-western suburbs to the very heart of the City. The journey only takes five minutes. The line was opened in August 1898, and carries an average of 30,000 passengers daily, most of them during the business rush hours. Nearly 40,000 yards of cables and wires have been laid in the course of the improvements.

\section{Fitting Schoolboys for the World of Work}

"Gumance Programs for Rural High Schools", by Mr. Paul Chapman (Washington, D.C. 10 cents), is a bulletin belonging to the 'Occupational and Guidance Service' established by the U.S. Office of Education in response to a widespread demand. It has been revised after critical comment on a limited. edition and shows once more the great elaboration of American education. High schools in rural districts have comparatively few pupils ; but, as the foreword points out, they are important for society as a whole, because "no large city in our Nation is producing enough children to maintain its population". Local conditions impose differences of training and the two models noticed in detail from New York State are much larger than the average rural school. But one of them is described as "basically agricultural" and both can supply selections of things worth doing. All schools of the sort can go in for "occupational information, the personal inventory, counselling, exploration, use of training facilities, placement, and follow-up". This last word means close attention to pupils after they have left school.

To keep all these activities going lays a heavy burden on teachers. At Nyack School "counselors" have a great deal to do. They interview employers and make a monthly report. Personal data are supplied concerning pupils seeking work; former students have a two-page questionnaire sent to them; and their employers are expected to say how they are getting on. It is evident that this wide vigilance must produce good results and reduce the number of misfits who are "everything by starts, and nothing long". If all teachers did anything like as much, they might steady those restless adolescents who do little good for themselves or anybody else and often end on the dole. The programmes offered go right to the root of unemployment, but they demand a good deal of time and patience.

\section{Ferns of Wales}

INTEREST in the British native flora and in the study of botany in general is so admirably stimulated and encouraged by the excellent series of exhibits in the National Museum of Wales that the descriptive handbook of Welsh ferns by Mr. H. A. Hyde, keeper of botany, and Mr. A. E. Wade, assistant in the Department, is assured of a wide welcome (Welsh Ferns : a Descriptive Handbook. By H. A. Hyde and A. E. Wade. Pp. $\mathbf{x}+132+11$ plates. Cardiff: 